Migration Studies - Review of Polish Diaspora nr 2 (172)/2019, http://www.ejournals.eu/Studia-Migracyjne/

10.4467/25444972SMPP.19.022.10848

\title{
Wspólnota losu czy wspólnota tożsamości? Uchodźcy kontra repatrianci
}

\author{
JOANNA KSIAZŻEK ${ }^{1}$ \\ Uniwersytet Mikołaja Kopernika w Toruniu
}

\begin{abstract}
Artykuł ukazuje funkcjonującą w przestrzeni społecznej konfrontację dwóch imigranckich grup repatriantów i uchodźców, które wraz z kryzysem uchodźczym w Europie oraz polityzacją problemów dotyczących zarówno jednej jak i drugiej grupy, ulegają społecznej polaryzacji. Do analizy zjawiska wykorzystywane są dwie antropologiczne kategorie: opozycyjna - Swoich i Obcych, oraz "jednocząca" - wspólnoty. Druga z nich traktowana jest jako objawiająca się na dwóch płaszczyznach - opartej na przynależności narodowej oraz opartej na dzieleniu wspólnego losu. Proces przypisywania obydwu grupom cech swojskości bądź obcości, włączania do wspólnoty bądź wykluczania z niej, ulega relatywizacji pod wpływem bieżących wydarzeń światowych i ich społecznego odbioru współkształtowanego w niemałym stopniu przez dyskurs oficjalny. Główną tezą wynikającą z analizy przedstawionej sytuacji jest, iż próby powoływania się na wspólnotę losu wszystkich migrantów dokonywane przez środowiska pro- imigranckie i pro-uchodźcze, w obliczu strachu wywołanego kryzysem związanym z napływem uchodźców, zderzają się w nierównej walce ze wspólnotą tożsamości mającą niejako pierwszeństwo w sytuacji zagrożenia. W tekście wykorzystuję wyniki dwuletnich badań prowadzonych w środowisku repatriantów oraz spostrzeżenia jako uczestnika i obserwatora debaty publicznej na temat uchodźców w Polsce.
\end{abstract}

Słowa kluczowe: migracje, solidarność, wspólnota losu, wspólnota tożsamości, swoi i obcy, uchodźcy, repatrianci, kryzys uchodźczy, repatriacja, polaryzacja.

\section{Community of fate, or community of identity? Refugees vs. repatriates}

The article shows the confrontation of two immigrant groups - repatriates and refugees - operating in the social space. This confrontation, together with the refugee crisis in Europe and the politicization of problems affecting both groups, becomes subject to social polarization. Two anthropological categories are used for the analysis of the phenomenon: the opposition of Us and Them (Swoi and Obcy), and the "unifying" notion of community. The second is treated as being manifested on

\footnotetext{
1 Kontakt: jksiazek@umk.pl
} 
two levels - on nationality and on sharing a common fate. The process of assigning the characteristics of homeliness or strangeness to both groups, of joining or excluding from the community, is relativized under the influence of current world events and their social reception has been coshaped to a large extent by the official discourse. The main thesis resulting from the analysis of the presented situation is that attempts to invoke the community of the fate of all migrants made by pro-immigrant and pro-refugee activists, in the face of fear caused by the crisis related to the influx of refugees, collide in an unequal struggle with the identity-community as a priority in an emergency situation. In the text, I use the results of two-year research conducted in the repatriate community and impressions as a participant and observer of the public debate on refugees in Poland.

Keywords: migrations, solidarity, community of fate, identity-community, folks and aliens, refugees, repatriates, refugee crisis, repatriation, polarization.

\section{Wprowadzenie}

Wraz z początkiem kryzysu migracyjnego w Europie, w celu lepszego zrozumienia sytuacji imigrantów i uchodźców oraz okazania im wsparcia, organizowane są różnego rodzaju działania - happeningi, wystawy, konferencje, warsztaty, wykłady, demonstracje poparcia i inne wydarzenia². Niektóre z tych wydarzeń akcentują moralny obowiązek obywateli państw, do których trafiają uchodźcy, wobec nich, niektóre natomiast odwołują się do poczucia empatii, skutkiem której ma być okazanie solidarności i pomocy uchodźcom, lub chociażby życzliwy stosunek do nich. W najogólniejszym wymiarze chodzi o współodczuwanie z istotami ludzkimi w potrzebie. Według Marty Jadwigi Pietrusińskiej jednym z czterech typów figur wyobrażeniowych (wizerunków) uchodźców funkcjonujących we współczesnym dyskursie edukacyjnym jest figura Inny-Ja, w której akcentuje się człowieczeństwo uchodźców.

W ramach zdarzeń komunikacyjnych tworzących tę figurę wyobrażeniową ich nadawcy chętnie odwołują się do empatii odbiorców poprzez użycie różnego rodzaju metod projekcyjnych i symulacyjnych - na przykład gra Przejście, podczas której uczestnicy wcielają się w role uchodźców, (...) (Pietrusińska 2018: 130).

Innym razem chodzi o współodczuwanie z osobami, z którymi łączy nas coś więcej niż bycie człowiekiem, a mianowicie podobne, trudne doświadczenia - akcentuje się więc momenty, kiedy my sami byliśmy imigrantami, uchodźcami, byliśmy gdzieś obcy. Działania te sprzyjać mają także procesowi odszyfrowania, bądź oswojenia obcości uchodźców, czemu przyświecają nie tylko cele poznawcze, ale przede wszystkim chęć wpłynięcia na naszą postawę względem uchodźców. Zwracają one uwagę na migracyjny charakter naszej kultury, przypominają Polakom, że do niedawna należeli,

2 Szczegółowego przeglądu (w odniesieniu głównie do woj. wielkopolskiego) oraz typologii działań kierujących naszą uwagę na uchodźców, zarówno edukacyjnych, jak i służących zorganizowaniu pomocy dla nich dokonuje W. Kuligowski (2018). 


\section{SM̂PP}

i w pewnym stopniu nadal należą do społeczności migrujących, że wielokrotnie byli uchodźcami ${ }^{3}$. Logikę taką prezentują także liczne artykuły prasowe i internetowe ${ }^{4}$. Natalia Bloch współorganizatorka wielowymiarowego wydarzenia „Wszyscy jesteśmy migrantami" ${ }^{5}$ wspomina, iż w debacie publicznej na temat kryzysu uchodźczego, której stała się uczestniczką "figura uchodźcy / migranta była prawie zawsze redukowana do kategorii Innego, jakbyśmy zapomnieli o naszej własnej, jakże złożonej i burzliwej, historii migracyjnej" (Bloch 2017: 333). Dlatego właśnie wspomniany projekt „powstał z zamiarem zabrania głosu w toczącej się debacie poprzez odwrócenie perspektywy, a tym samym uruchomienie mechanizmu empatii i opowiedzenie o nas jako o migrantach, (od)zyskanie naszej własnej pamięci migracyjnej" (Bloch 2017: 334). Przywoływanie uchodźczych i imigranckich doświadczeń Polaków w kontekście podobnych losów współczesnych uchodźców i migrantów jest więc powoływaniem się na wspólnotę losu.

Pojęcie wspólnoty nieodłącznie wiąże się z pojęciem zbiorowej tożsamości rozumianej jako poczucie (jednostek) przynależności do grupy. W ujęciu konstruktywistycznym oraz interakcjonizmu społecznego tożsamość społeczno-kulturowa podlega zmianom i przekształceniom w wyniku ciągłej interakcji czynników społecznych, na jej treści wpływ mają jednak określone elementy konkretnego systemu społeczno-kulturowego (por. Szwed 2003: 61).

Czynnikiem decydującym o przynależności etnicznej, narodowej czy kulturowej jest samoświadomość jednostki, jej autoidentyfikacja, opierająca się głównie na subiektywnym odczuciu (por. Babiński 1997: 23-24). Wiąże się z nią poczucie łączności z grupą i solidaryzowanie się z nią w zbiorowych akcjach (por. Obrębski 2005: 90). Poczucie to kształtuje się rzecz jasna przy pomocy tzw. obserwowalnych, zewnętrznych cech

${ }^{3}$ W ten nurt wpisują się m.in. wystawa „Wszyscy jesteśmy migrantami. Listy polskich emigrantów z Ameryki końca XIX wieku” Centrum Kultury Zamek w Poznaniu 23.09-27.11.2016; projekt „Wszyscy jesteśmy migrantami" przygotowany przez Instytutu Etnologii i Antropologii Kulturowej i Centrum Badań Migracyjnych UAM, 11-14.06.2016; wydarzenie "Polacy też byli uchodźcami" organizowane przez Pracownię Duży Pokój 11 X 2016 w Warszawie (debata dotyczącą doświadczania uchodźctwa przez polskich obywateli i obywatelki) zorganizowana z okazji Dnia Solidarności z Uchodźcami; wykład prof. Waldemara Kuligowskiego w serii „Arcydzieła, arcymyśli..." pod tytułem „Uchodźcy a Polska: historia, kultura, polityka", zarejestrowany w listopadzie 2015 roku na Uniwersytecie Adama Mickiewicza w Poznaniu; http:// usf.amu.edu.pl/filmoteka/wyk-ady-uniwersyteckie/wyk-ad-63-prof-waldemar-kuligowski-uchod-cy-polskahistoria-kultura-polityka.

${ }^{4}$ Tak na przykład na stronie uchodzcy.info informacje na temat okresów i epizodów uchodźstwa w historii narodu polskiego opatrzone są zapytaniem o spłatę długu dziejowego, który wówczas zaciągnięto (http://uchodzcy.info/infos/polacy-tez-byli-uchodzcami/) (dostęp: 17 X 2018). Podobną funkcję spełnia artykuł Krzysztofa Adamskiego w Newsweek plus pt. „Polacy pamiętajcie! My też byliśmy uchodźcami!" https://www.newsweek.pl/wiedza/historia/polacy-pamietajcie-my-tez-bylismy-uchodzcami-dzienuchodzcy/16jxkyb (dostęp: 17 X 2018).

${ }^{5}$ Zob. przyp. 1. 
kulturowych jako świadectw odrębności grupy (por. Szacki 2004: 22) oraz pod wpływem oceny płynącej ze strony innych osób (por. Szwed 2003: 34, Siemieńska 1978: 31).

Przyjęcie istnienia wielu rodzajów identyfikacji zbiorowej jako płaszczyzn rozumianej całościowo zbiorowej tożsamości jednostki lub traktowanych jako odrębne tożsamości wiąże się z sytuacyjnością ich występowania. Jednostki mogą mieć więc „wielorakie tożsamości” i zgodnie z wymogami chwili przechodzić od jednej roli i tożsamości do innej (Smith 2009: 42, por. Kłoskowska 2005).

W kontekście społecznych mechanizmów konstruowania zbiorowej tożsamości, zwracam uwagę na znaczenie w tym procesie Innego, wobec którego następuje proces różnicowania i definiowania odrębności grupy. Zgodnie z tezą Józefa Obrębskiego „własny wizerunek [grupy] jest jakby refleksem tych kontrastów, na których podstawie grupa definiuje odrębność grup innych" (Obrębski 2005: 93). O tym zaś, jak rozłożone zostaną kategorie porządkujące na „swoich” i „obcych” pomiędzy dwiema grupami, decyduje kontekst kontaktu społecznego, który Floriana Znaniecki nazwał „podłożem styczności społecznej” wraz z towarzyszącymi mu wartościami (Znaniecki 1930). Zapewne podobny rodzaj zmiennych okoliczności społecznych miała na myśli Antonina Kłoskowska twierdząc, iż elementy różnicujące takie jak religia, język, terytorium, wspólnota krwi, nie są wykorzystywane zawsze w ten sam sposób, lecz zmieniają się w zależności od konfiguracji czynników społecznych, politycznych czy ekonomicznych w obrębie grupy własnej lub sąsiedniej (Kłoskowska 2005: 39). Podobne w swym wydźwięku jest spostrzeżenie Fredrika Bartha, według którego konstruowanie tożsamości zbiorowej odbywa się w oparciu o tzw. cechy graniczne. Zdaniem antropologa są nimi nie „obiektywne”, charakterystyczne cechy kulturowe, lecz te spośród rezerwuaru wartości etnicznych, które najlepiej oddają różnice międzygrupowe w danej sytuacji, podlegać mogą one zatem zmianom w zależności od celów i potrzeb (Barth 2004: 352-353).

Identyfikacja narodowa jako jeden z wielu sposobów identyfikacji, w wielu sytuacjach okazuje się zasadnicza i decydująca (Smith 2009: 42). Wspólnota narodowa jako rodzaj zbiorowej tożsamości odnosi się rzecz jasna do narodu, rozumianego jako twór wyobrażony (Obrębski 2005:157, Anderson 1997). Na potrzeby niniejszego tekstu abstrahuję od teorii genezy wspólnoty narodowej, stopnia udziału w niej państwa, polityki i władzy, odnosząc się raczej do sposobów funkcjonowania tej wspólnoty w umysłach jej przedstawicieli. Niezależnie więc od tego czy naród rozumiany jest jako efekt stopniowej kumulacji grupowych doświadczeń sięgających korzeniami do etniczności (Smith 2009, por. Kłoskowska 2005), czy rozumiany jest na sposób dyskursywny, jako zdarzenie oraz fundamentalna forma poznawcza i społeczna, a nie właściwości danej zbiorowości (Brubaker 1998), społecznie funkcjonuje on jako realnie istniejąca rzeczywistość - narody traktowane są jako rzeczywiste byty, społeczności, substancjalne i trwałe zbiorowości (Brubaker 1998: 15).

W świetle przytoczonych informacji nasuwa się pytanie - czy świadomość 240 wspólnych losów i doświadczeń implikuje rodzaj znaczącej więzi i generuje realnie 


\section{SM̂PP}

oddziałującą wspólnotę w sensie wyobrażeniowej zbiorowości, będącej jednocześnie źródłem identyfikacji zbiorowej. Innymi słowy, czy możliwe jest, by wspólnota losu była jednocześnie wspólnotą tożsamości. I czy byłaby wtedy na tyle silna, by wykraczając ponad identyfikacje narodowe (także kulturowe, czy „cywilizacyjne”) zaistnieć w określonych okolicznościach jako identyfikacja nadrzędna.

By przybliżyć się do odpowiedzi na to pytanie przedstawię kilka sposobów funkcjonowania wspólnoty losu na przykładzie, bliskiej mi z racji zainteresowań badawczych, społeczności polskich repatriantów z Kazachstanu6 ${ }^{6}$ następnie odniosę się do roli wspólnoty narodowej w relacjach między repatriantami a społeczeństwem przyjmującym, by w końcu naświetlić role tych dwóch kategorii we współczesnym dyskursie migracyjnym i uchodźczym.

\section{Wspólnota losu na przykładzie repatriantów}

Wspólnota losu w przypadku kazachstańskich Polaków, a więc i późniejszych repatriantów, ma wiele płaszczyzn. Poczucie wspólnoty wszystkich osób deportowanych pojawia się wskutek traumatycznych przeżyć i warunków życia podczas deportacji i w czasie życia pod komendanturą. Jej istnienie odnotowuje badacz diaspory polskiej w Kazachstanie, A. Posern-Zieliński, który twierdzi, że odrębność etniczna Polaków przejawia się w sferze języka, religii i tradycji rodzinnej ukształtowanych przed deportacją, a także świadomości wspólnoty przesiedleńczych losów i sytuacją walki o byt w początkowej fazie pobytu w Kazachstanie (Posern-Zieliński 1996: 537).

Wspólnota losu ludności deportowanej była czynnikiem jednoczącym wszystkie narodowości, które doświadczyły tego samego przeżycia. Dzielenie losu pod komendanturą potrafiło zjednoczyć Polaków, Niemców oraz inne narodowości w geście sąsiedzkiej pomocy i wioskowej solidarności. Przeżywanie takiego samego cierpienia było czynnikiem spajającym społeczność wioskową i spychało różnice pochodzeniowe i kulturowe na dalszy plan. Równocześnie, wspólnota ta odegrała ważną rolę w konsolidacji grupy Polaków jako grupy narodowej, nie tylko poprzez świadomość wspólnej historii, która należy do podstawowych czynników kształtujących poczucie zbiorowej tożsamości grupy, ale także dzięki świadomości, że los, jaki ich spotkał, spotkał ich właśnie dlatego, że byli Polakami . Choć doświadczenia osób deportowanych od doświadczeń najmłodszych członków polskiej diaspory dzielą pokolenia, życie

${ }^{6}$ Badania, będące podstawą mojej pracy doktorskiej, prowadzone były w latach 2011-2012, metodą wywiadów swobodnych ukierunkowanych (60 wywiadów) i zorientowane były na uchwycenie specyfiki dylematów tożsamościowych, towarzyszących repatriantom z Kazachstanu. Wyniki badań zostały opublikowane w książce pt. Stamtąd - tu. Obrazy tożsamości kazachstańskich Polaków w kontekście repatriacji (Książek 2018).

7 Represje skierowane do polskiej (także niemieckiej i żydowskiej) ludności Ukrainy sowieckiej w 1936 roku, wskutek których znalazła się ona w Kazachstanie nosiły charakter strategiczny (prewencyjna ochrona granic) i miały podłoże wybitnie narodowościowe. 
w Kazachstanie potomków ludności przesiedlonej jest wciąż namacalnym dowodem ich uczestnictwa w doświadczeniu deportacji.

Swego rodzaju przedłużenie i kontynuację scalającej społeczność wspólnoty losu, stanowi więź charakterystyczna dla środowiska współczesnych repatriantów. Za przykład typowej odpowiedzi na pytanie o więź łączącą środowisko repatriantów, może posłużyć wypowiedź 60-letniej repatriantki: Bo taki sam los ich spotkał, tak samo ich rodziny zesłali wbrew ich woli. Taka wspólnota losu nas łączy.

Po emigracji do Polski więź łącząca potomków osób deportowanych zostaje zachowana i poszerzona o repatriantów z całego obszaru byłego Związku Radzieckiego. Dodatkowym elementem konsolidującym tę grupę staje się z czasem inny rodzaj wspólnoty losu, mianowicie oparty na przeżywaniu tych samych imigracyjnych doświadczeń, zwłaszcza w postaci typowych dla repatriantów problemów, pojawiających się w nowej ojczyźnie. Znajomość pewnego typu problemów z autopsji zdecydowanie ułatwia, a wręcz umożliwia okazanie pomocy osobom, których ten problem dotyka, natomiast nieznajomość i niezrozumienie tych problemów czyni obojętnym wobec osoby borykającej się z nimi. Zdaniem repatriantów nikt inny nie potrafi tak dobrze zrozumieć specyfiki i charakteru kryzysu, będącego na pewnym etapie udziałem niemalże każdego przesiedleńca z byłych republik radzieckich, niż jemu podobni. W związku z tym to przeważnie we własnym gronie szukają oni wsparcia i zrozumienia (por. Kość-Ryżko 2011:168). Zależność ta powoduje, że intensywność i głębia relacji, a także poczucie więzi i porozumienia w grupie repatriantów są zdecydowanie silniejsze niż w przypadku relacji z przedstawicielami społeczeństwa przyjmującego (Książek 2018: 94-95)8. Oparte na niniejszych podstawach poczucie wspólnoty losu objawia się także we wzajemnych relacjach współczesnych repatriantów z niegdysiejszymi przesiedleńcami (ekspatriantami) z byłych Kresów Wschodnich, przesiedlanymi na tzw. Ziemie Odzyskane po II wojnie światowej. Opisywane przez repatriantów spotkania z dawnymi przesiedleńcami cechuje obustronna serdeczność, wręcz natychmiastowy odruch niesienia pomocy i oferowanie wsparcia nowym repatriantom przez dawnych przesiedleńców, a także okazywanie bezwarunkowej sympatii i ufności oraz porozumienie bez zbędnych słów (Książek 2018: 98). Dla więzi łączącej te dwie odrębne grupy znaczenie ma wymiar terytorialny w postaci wspólnego pochodzenia „zza Buga”, lecz nie mniej ważnym czynnikiem jednoczącym obie grupy jest znowu z gruntu problematyczna i naznaczona trudnościami sytuacja Polaka - przesiedleńca, przybysza, nowego, innego, obcego, a przede wszystkim zagubionego w nowej rzeczywistości, a także świadomość przeżywania trudnego, wieloletniego procesu akulturacji i aklimatyzacji do zastanych warunków.

8 Por. także badania Julii Gorbaniuk wśród studentów polskiego pochodzenia (Gorbaniuk 1998: 93), w których autorka ukazuje, że mimo posiadania relacji w obydwu grupach, powiernikami studentów są niemal zawsze osoby z grona Polaków ze Wschodu. 


\section{SM̂PP}

\section{W stronę wspólnoty narodowej}

Większość kazachstańskich Polaków decydujących się na osiedlenie w Polsce argumentuje swoją decyzję między innymi poczuciem więzi z rodakami w kraju, powołuje się zatem na wspólnotę narodową. Nic dziwnego, ich potomkowie zostali zesłani do Kazachstanu ze względu na przynależność narodową - Kazachstańscy Polacy zostali deportowani do Kazachstanu z terenów Ukrainy sowieckiej w ramach akcji depolonizacyjnej, kierowanej przez stalinowski aparat bezpieczeństwa, której zadaniem było oczyszczenie zachodnich republik ZSRR z żywiołu polskiego'. Przynależność repatriantów do narodu polskiego stanowi także fundament akcji repatriacyjnej, jej wydźwięk docierający do Polaków w Kazachstanie sugeruje wizję przyszłych relacji społecznych po przyjeździe do Polski.

Już sam termin re-patriacja funkcjonujący w przestrzeni publicznej, rozumiany dosłownie - jako powrót do ojczyzny, dostarcza swoistej pre-definicji i jednoznacznej klasyfikacji przybywających repatriantów jako Polaków wracających po latach zesłania, przyczyniającej się zapewne do społecznej akceptacji tej grupy pośród nas. W oficjalnym przekazie niewiele jest miejsca na refleksję na temat kształtu i specyfiki kultury polskiej, jaką zabrali ze sobą Polacy z Ukrainy sowieckiej ${ }^{10}$, ani przeobrażeń, jakie zachodziły w obrębie zbiorowej tożsamości kolejnych pokoleń Polaków pozostających poza Polską, w bardzo specyficznych warunkach „emigracyjnych”, a tym bardziej, jak wszystkie te czynniki wpływają na aklimatyzację wspomnianej grupy we współczesnej Polsce.

Życie przez 20 lat pod nadzorem komendantury, dyskryminacja polskiej ludności w dostępie do edukacji i stanowisk oraz chęć pozbycia się piętna deportowanego Polaka jako wroga narodu powodowały niejednokrotnie rezygnację z deklarowania polskiej narodowości na rzecz innej, najczęściej rosyjskiej. W kolejnych latach, czynniki takie jak brak kontaktu z krajem i utrudniony kontakt z językiem polskim (brak książek i materiałów do nauki języka), zakaz działalności duszpasterskiej, propagowanie modelu człowieka sowieckiego na każdym poziomie edukacji oraz łączenie się wzorców kulturowych wskutek zawierania małżeństw mieszanych, powodowały zmiany kulturowych cech zewnętrznych oraz na poziomie świadomościowym polskiej diaspory.

Wraz z powstaniem suwerennego Kazachstanu po upadku imperium sowieckiego polskość wśród kazachstańskich Polaków zaczęła się odradzać. Powstałe straty były jednak trudne do odrobienia. Osoby polskiej narodowości prezentują od lat najniższy wskaźnik posługiwania się językiem ojczystym wśród diaspor w postradzieckiej Azji

9 Szerzej na temat politycznego kontekstu wydarzeń oraz samych akcji deportacyjnych zob. Iwanow 1991, por. także Kijas 1993, Eberhardt 1994, Patek 2001, Stroński 2007.

${ }^{10} \mathrm{Na}$ długo przed deportacją tożsamość etniczna tej ludności ukształtowała się w sytuacji pogranicza etnicznego i w swym kształcie różniła się od polskiej etniczności pielęgnowanej w granicach Polski „nie-kresowej”. Szerzej na temat zob. Jasiewicz 1992, Szynkiewicz 1996, Iwanow 1991, Kupczak 1994. 
Środkowej - w latach 1999 i 2009 jedynie 9\% Polaków deklarowało język polski jako swój język ojczysty ${ }^{11}$.

Stosunek Polaków zamieszkałych w Polsce do repatriantów posiada wymiar oficjalny i nieoficjalny. Na gruncie formalnym, jak wspomniałam, stosunek do repatriantów jest niejako „programowo"12 - pozytywny. Podkreślany jest przede wszystkim aspekt przynależności narodowej repatriantów, która zobowiązuje państwo polskie do zadośćuczynienia im za doznane z tego powodu krzywdy, akcentowaniu podlega zatem ich polskość - z tej perspektywy są rodakami, a więc "swoimi". Oprócz względów ideowych, nie bez znaczenia w tym podejściu są względy polityczne, demograficzne oraz wizerunkowe ${ }^{13}$. Retoryce tej podporządkowana jest także większość przekazów medialnych - przypominają one fakt wywózki, trudy deportacji oraz wieloletniej przymusowej egzystencji na obczyźnie, a w końcu powrót "naszych ubogich krewnych" do ojczyzny po latach zesłania i przymusowego pobytu w ZSRR. Ładunek emocjonalny, który niosą ze sobą te obrazy, bazuje na wspólnocie, której podstawą jest narodowość.

Jak relacjonuje zdecydowana większość badanych przeze mnie repatriantów, bywa, że ich przynależność do narodowej wspólnoty zostaje zakwestionowana. W kontakcie z repatriantem na pierwszy plan wysuwa się najczęściej jego "wschodni” akcent lub po prostu język rosyjski, który automatycznie staje się oznaką obcości. Obcości wzmocnionej przez stereotypowe skojarzenia ze Związkiem Radzieckim i Rosją, które bynajmniej nie są pozytywne ze względu na zaszłości historyczne, na których bazuje niechętny stosunek Polaków do Rosjan ${ }^{14}$. Skojarzenie takie dość często prowadzi do typowego nieporozumienia w postaci przypisywania fałszywej identyfikacji, kiedy to osoby polskiego pochodzenia z Kazachstanu uznawane są mylnie za Rosjan, bądź też przedstawicieli innej narodowości zza wschodniej granicy Polski, i określane zbiorczą nazwą - "ruscy". Etykieta ta jest wstępem i uprawomocnieniem traktowania lekceważącego, obraźliwego i ośmieszającego oraz odmawiania określanym przez nią podmiotom praw, jakie przysługują innym obywatelom.

Posługiwanie się językiem rosyjskim bądź mówienie ze wschodnim akcentem oraz przywiązanie do kultury rosyjskiej kłóci się w powszechnym mniemaniu z "byciem Polakiem", wszak język stanowi w Polsce jedno z najważniejszych w hierarchii kryteriów tożsamościowych (Smolicz 1984: 35). Jak dowodzą badania M. Sadowskiego,

11 Агентство Республики Казахстан по статистике, Начиональный состав, вероисповедание и владения языками в Республике Казахстан Итоги Начиональной переписи населения 2009 года в Республике Казахстан, Астана 2010; ПЕРЕПИСЬ НАСЕЛЕНИЯ РЕСПУБЛИКИ КАЗАХСТАН 2009 ГОДА, Kраткие umоги, Астана 2010, http://www.stat.kz/p_perepis/Pages/default.aspx; (dostęp: 13.06.2013).

12 Problem diaspory polskiej na Wschodzie i kwestia jej repatriacji od wielu lat podlega w Polsce upolitycznieniu (por. Lesińska 2017).

13 W telewizji i internecie można znaleźć wiele filmów relacjonujących uroczystości oficjalnego przyjęcia przez gminę repatriantów z udziałem lokalnych bądź centralnych władz lub pokazujących wprowadzanie się nowo przybyłych repatriantów do świeżo wyremontowanych mieszkań.

14 Por. np. Polacy wobec innych narodów. Komunikat z nadań CBOS nr 37/2018, s. 2. 


\section{SM̂PP}

najważniejszym kryterium przynależności do narodu polskiego, formułowanym przez przedstawicieli kazachstańskiej Polonii, jest „czuć się Polakiem”, w dalszej kolejności dopiero wymieniane są kryteria takie jak urodzenie w polskiej rodzinie, bycie katolikiem i znajomość języka polskiego (Sadowski, Czerniawska 1999: 81). Wydaje się, że w Polsce, w sytuacji konfrontacji z miejscowymi Polakami, subiektywne przekonania i odczucia repatriantów, dotyczące ich identyfikacji narodowej, tracą na znaczeniu na rzecz kryteriów zewnętrznych, co powoduje, że powoływanie się przez nich na swą polskość odczytywane jest niekiedy jako nieuprawniona uzurpacja. Repatrianci mają zatem utrudniony dostęp do wspólnoty narodowej - mechanizm jej funkcjonowania ujawnia tu swoje wykluczające oblicze. Dodać trzeba, że nieprzyjazny stosunek do repatriantów oraz kwestionowanie ich polskości mają także swoje podłoże ekonomiczne - wiąże się ono z konkurencją na rynku pracy oraz z pewnego rodzaju przywilejami, które otrzymują repatrianci w postaci różnego rodzaju zapomóg finansowych, ułatwień w przydziale mieszkania czy pomocy w znalezieniu pracy.

Zarysowana sytuacja implikuje często asymilacyjny model adaptacji społeczno-kulturowej, polegający na maksymalnym upodobnieniu się do otaczającej większości (por. Grzymała-Kazłowska, Grzymała-Moszczyńska 2012: 51), co wymusza pozbycie się cech świadczących o związkach z inną niż polska kulturą, kulturą - dodajmy w której osoby te się wychowały i która stanowi integralną część ich tożsamości. Tak więc nawet jeśli, jak dowodzą niektórzy badacze (np. Weinar 2003: 180), na tle obcokrajowców i imigrantów repatrianci adaptują się najszybciej i najmniej narzekają na dyskryminację, adaptacja ta odbywa się bardzo dużym kosztem.

\section{Kryzys uchodźczy szansą dla repatriantów?}

Wraz z nastaniem kryzysu uchodźczego w Europie Polacy ze Wschodu zaczęli stanowić grupę imigrancką potencjalnie konkurującą o miejsce w Polsce z uchodźcami. „W Polsce dyskurs społeczny skupia się obecnie na tym, czy Polska powinna przyjąć odległych kulturowo uchodźców z Syrii, skoro tysiące Polaków przebywa w byłych republikach Związku Radzieckiego, a kraj nie ma środków na ich sprowadzenie do kraju" - pisała w 2017 roku Elżbieta Czapka (Czapka 2017: 77).

Pewnych wskazówek dotyczących charakterystyki toczącego się procesu, dostarcza sformułowanie przez TNS pytania sondażowego, skierowanego do przedstawicieli społeczeństwa polskiego w listopadzie 2015 roku ${ }^{15}$. Należało w nim określić swój stosunek do opinii, iż „Polska powinna w pierwszej kolejności sprowadzić Polaków ze wschodu - dawnych zesłańców, a dopiero później przyjmować uchodźców z Afryki i z Bliskiego Wschodu". 73\% respondentów zgodziło się z tą opinią. Sposób ujęcia

15 Polacy o uchodźcach, TNS listopad 2015, http://www.tnsglobal.pl/wp-content/blogs.dir/9/files/2015/11/K.072_Polacy_o_uchodzcach_O10a-15.pdf (dostęp: 18 XI 2018). 
problematyki w formie alternatywy - albo repatrianci albo uchodźcy, sytuuje obydwie grupy na dwóch przeciwległych biegunach. Poruszona w powyższym pytaniu kwestia jest tematem dyskusji społecznej i pojawia się często w komentarzach do informacji czy materiałów filmowych zamieszczanych w Internecie, dotyczących zarówno kazachstańskich Polaków i repatriantów, jak i uchodźców. Niemała część komentatorów to osoby przeciwstawiające sobie te dwie potencjalne grupy migrantów. Nieco upraszczając, można więc powiedzieć, że krytyka repatriantów (np. w mediach społecznościowych) w rodzaju „Cóż z niego za Polak, skoro nie mówi po polsku” ustępuje miejsca argumentom o potrzebie przyjmowania repatriantów jako Polaków w opozycji do przyjmowania obcych: „Po co przyjmować obcych, skoro tylu naszych czeka na powrót do Polski w Kazachstanie?". Nierozwiązana sprawa Polaków na Wschodzie ${ }^{16}$ staje się więc argumentem uzasadniającym i usprawiedliwiającym nieprzyjmowanie uchodźców.

Na podstawie przywołanych sondaży trudno stwierdzić, czy w związku z pojawieniem się kwestii uchodźców, rzeczywista postawa wobec repatriantów ulega zmianie. Podobnie, uzyskanie procentowej odpowiedzi na przytoczone wyżej sondażowe pytanie nie daje pewności czy osoby potwierdzające opinię w ogóle są skłonne przyjmować uchodźców, mimo że wskazywałaby na to logika zdania. Wydaje się jednak, że pozycja repatriantów zmieniła się raczej na potrzeby retoryki anty-uchodźczej niż pro-repatrianckiej.

Stosowanie narracji polaryzującej grupy imigranckie zauważyć można także na poziomie działań politycznych, a także państwowych. Pod koniec 2015 roku wiceminister, odpowiedzialny za politykę migracyjną Polski, wyrażając krytykę wobec unijnych dyrektyw dotyczących relokacji uchodźców w krajach Unii Europejskiej, zapowiedział jednocześnie otwarcie polskiej polityki migracyjnej na "kierunek wschodni”, a jednym z jej elementów, oprócz przyjmowania imigrantów z Ukrainy, miała być właśnie repatriacja (Łodziński 2017: 64-65). Można także stwierdzić, że przyjęcie za punkt honoru sprowadzenia Polaków ze Wschodu do kraju, czego wyrazem mają być ułatwienia wskutek nowelizacji Ustawy o repatriacji17, odbywa się przy jednoczesnym

16 Działania w ramach dotychczasowej Ustawy o repatriacji obowiązującej od 2001 roku, pozostawiające w gestii samorządów decyzję o przyjęciu rodziny repatriantów w zależności od posiadania warunków lokalowych, nie rozwiązały kwestii powrotu do Polski Polaków ze Wschodu. W bazie Rodak - ewidencji wniosków repatriacyjnych osób, oczekujących na zaproszenie ze strony gminy polskiej, wciąż zarejestrowanych jest kilka tysięcy osób. Wg Raportu NIK (Informacja o wynikach kontroli, Realizacja polityki migracyjnej Polski w odniesieniu do cudzoziemców deklarujących polskie pochodzenie, Warszawa 2014 (https://www. nik.gov.pl/plik/id,7566,vp,9497.pdf, s. 13.) w 2013 roku było to 2625 osób. W 2017 roku nowelizowano ustawę o repatriacji, podejmując szereg decyzji mających usprawnić sprowadzanie kazachstańskich Polaków do Polski i ułatwić im start w nowym kraju.

17 Nowelizowana ustawa wprowadza m.in. poszerzenie kryteriów uznania za osobę polskiej narodowości, przyznanie równego statusu członkom rodziny repatrianta, powołanie nowych instytucji i funkcji ds. repatriantów, ułatwienia organizacyjne dla gmin czy koncepcję ośrodków adaptacyjnych (prawo.sejm.gov. pl/isap.nsf/DocDetails.xsp?id=WDU20001061118). Od 2016 r. funkcjonuje ośrodek adaptacyjny w Pułtusku prowadzony przez Stowarzyszenie „Wspólnota Polska” Dom Polonii w Pułtusku, w którym obecnie przebywa 120 osób (http://repatriancipultusk.pl/o-nas/). 


\section{SM̂PP}

ograniczeniu integracyjnych działań skierowanych do uchodźców i innych migrantów. Wraz ze zmianą założeń polskiej polityki migracyjnej, MSWiA od 2015 roku ograniczyło lub wstrzymało finansowanie działań integracyjnych dla cudzoziemców prowadzonych przez organizacje społeczne ze środków Funduszu Azylu Migracji i Integracji (Klaus, Ostaszewska-Żuk, Szczepanik 2017). Z kolei wśród publicystycznych propozycji usprawnienia akcji repatriacyjnej pojawiają się też sugestie, by w sytuacji niewystarczającej liczby ośrodków adaptacyjnych dla repatriantów stworzyć dla nich miejsca w podlegających MSWiA ośrodkach, które dzisiaj przeznaczone są dla cudzoziemców" (Kozubal 2018).

W kontekście znaczenia mediów trzeba podkreślić, że styczność społeczna z uchodźcami, pomijając ograniczone przestrzennie kontakty społeczne z Czeczeńcami w okolicach ośrodków dla uchodźców, jest stycznością nie bezpośrednią, a zapośredniczoną medialnie - najczęściej przez przekazy i informacje płynące z innych części Europy i świata. Styczność wirtualna ma jednak bardzo realne i wymierne skutki - wpływa na konkretne postawy i zachowania członków społeczeństwa nie tylko wobec uchodźców, ale także wobec osób wyróżniających się kolorem skóry, językiem czy wyznaniem.

Na potrzeby wspomnianego dyskursu odbywa się zatem swoista zmiana konfiguracji Swój - Obcy na drodze relatywizacji stopnia obcości repatriantów wskutek pojawienia się grupy odbieranej jako bardziej obca, czyli uchodźców. Wobec pojawienia się nowego Obcego repatrianci automatycznie stają się bardziej „swoi”, a na pewno traktowani są jako bardziej zasługujący na przyjęcie w państwie polskim niż demonizowani uchodźcy, zgodnie z kalkulacją, że ewentualny sugerowany niesprawiedliwy podział dóbr, czy przywiązanie repatriantów do rosyjskiej kultury i języka, są mało znaczącymi szczegółami wobec rzekomego zagrożenia ze strony nie tylko ekstremistów islamskich w związku z terroryzmem, ale pojmowanej całościowo kultury i obyczajów Islamu, które nieść mają ze sobą uchodźcy.

Repatrianci, chcąc nie chcąc, stali się dla uchodźców przeciwwagą, grupą, na tle której uchodźcy stają się jeszcze bardziej obcy. W społecznym dyskursie, hołdującym wartościom patriotyczno-narodowym, wykorzystany zostaje pochodzeniowy, etniczny potencjał repatriantów, pozwalający poszerzyć stosowane dotąd kryteria i włączyć ich do narodowej wspólnoty niejako w akcie niezgody na obecność przedstawicieli odmiennej religii i kultury. Miejsce mitycznego wroga w postaci "ruskiego", z którym budzili skojarzenia repatrianci, będącego efektem „zorientowanego na naród” tworzenia uproszczonych i demonizujących charakteryzacji narodowego Innego (por. Brubaker 2009: 25), zajmują uchodźcy z krajów muzułmańskich. W ten sposób rosyjskojęzyczni i nieco odmienni, lecz jednak wywodzący się ze wspólnego - słowiańskiego - kręgu kulturowego repatrianci, stają się "swoimi”. Analogiczne przesunięcie ma miejsce na płaszczyźnie ekonomicznej - w myśl zasady: jeśli chcemy wydawać pieniądze na pomoc, to lepiej pomagać swoim niż obcym, czy też bliższym obcym niż obcym najdalszym. 
W nawiązaniu do przytoczonych we wprowadzeniu teorii Znanieckiego i Obrębskiego można stwierdzić, że forsowana i dominująca w dobie kryzysu uchodźczego konceptualizacja Innego, wobec którego kształtuje się nasza tożsamość, powoduje zmianę kryteriów przynależności do wspólnoty stojącej u podstaw tejże tożsamości. Jeśli zasada zmienności „podłoża styczności społecznej” w kontekście relatywizacji obcości działa w ujęciu synchronicznym (ta sama osoba może być uznawana za obcą lub swoją w tym samym czasie, w zależności od okoliczności społecznych) (Znaniecki 1930), to tym bardziej w ujęciu diachronicznym, w związku z wydarzeniami, które następują w czasie, jak na przykład przybycie uchodźców do Europy. Barth'a koncepcja roli cech granicznych w procesie konstruowania tożsamości zbiorowej, pozwala zaś zauważyć, iż okolicznością (zmienną), wobec której następuje zmiana cech dla tożsamości granicznych jest poszerzenie zakresu kategorii Innego/Obcego (jako wroga) do postaci całego świata muzułmańskiego. W odpowiedzi na zmianę tych okoliczności, zamiast przyjęcia wyzwania ponadkulturowej wspólnoty losu i podjęcia odpowiednich do niego działań, następuje poszerzenie granicznych kryteriów przynależności narodowej, umożliwiające włączenie repatriantów do tejże wspólnoty.

\section{Dla kogo tolerancja?}

W trakcie badań w środowisku repatriantów, zadawałam moim rozmówcom pytanie, czy uważają oni społeczeństwo polskie za tolerancyjne. Jedna z osób, młoda kobieta, odpowiedziała: Społeczeństwo jest tolerancyjne, ale nie dla nas! Murzynów lepiej traktują od nas. Czeczenów to by po nogach całowali! Niemców bardziej szanują, a to za co?

Wypowiedź ta obrazuje wiele poruszonych w tekście wątków. Sugeruje wybiórcze stosowanie zasady poprawności politycznej, znacznie wyraźniejsze np. w przypadku osób czarnoskórych, zaś na przykładzie uchodźców z ogarniętej wojną Czeczenii ukazuje sprzyjający tolerancji wpływ nagłaśniania sytuacji przybywających do Polski grup imigranckich. Świadomość społeczna na temat imigrantów i ich akceptacja zależy w dużej mierze od tego, jak często, na jaką skalę i z jakim stopniem rzetelności prezentuje się kulturę, historię i bieżącą sytuację danej grupy imigranckiej. Wydaje się, że sprawa repatriantów została pod tym kątem na pewnym etapie pominięta, być może w oparciu o, sugerowany już powyżej, dość bezrefleksyjny pogląd, że skoro są to Polacy, to specjalne akcje uświadamiające społeczeństwo na ich temat są niepotrzebne. Kwestia oficjalnego uznania specyficznej odmienności repatriantów (odbieranej społecznie jako „obcość”), wymagającej działań informacyjnych i edukacyjnych wobec społeczeństwa przyjmującego oraz integracyjnych dla repatriantów, jest bardzo delikatna i wymaga wiele wyczucia. Celowe niezauważanie tej odmienności jest wygodnym, z punktu widzenia nakładu sił i środków, zaniechaniem przyczyniającym się do pogłębienia problemów adaptacyjnych tej grupy. Pozytywnym 


\section{SM̂PP}

przykładem szeroko zakrojonej informacyjnej akcji społecznej dotyczącej repatriantów, jest niedawna kampania informacyjna Stowarzyszenia Wspólnota Polska i Polskiego Radia zorganizowana pod hasłem „Wielki powrót”, w ramach której, w okresie lipiec 2017 - styczeń 2018, w radiowej „Jedynce” emitowano szereg cyklicznych audycji dotyczących Polaków na Wschodzie i repatriacji. Nadmienić jednak trzeba, że niekiedy (za sprawą zaproszonych gości, wykazujących postawę krytyczną wobec relokacji uchodźców w sytuacji ograniczeń w sprowadzaniu Polaków ze Wschodu) wpisuje się ona w retorykę alternatywy „uchodźcy a l bo repatrianci”. Powołując się na opinie tych drugich, zaproszona do studia eurodeputowana stwierdziła, że decyzja o relokacji do Polski siedmiu tysięcy uchodźców została „bardzo boleśnie przyjęta przez Polaków na Wschodzie, bo poczuli się jakby im napluto w twarz"18.

Słowa wypowiedziane przez repatriantkę można odczytać także jako refleks konfliktu interesów, podobnego do tego, któremu dają wyraz Polacy, narzekając na uprzywilejowanie repatriantów, bądź niekorzystny dla nich ekonomicznie efekt konkurowania z ukraińskimi imigrantami na rynku pracy. W omawianym przypadku nie chodzi jednak o jakiekolwiek przywileje, lecz o stopień tolerancji, większy wobec jednej grupy, mniejszy wobec innej. Swoisty wyrzut zawarty w tym zdaniu skierowany jest w stronę polskiego społeczeństwa (a także sfer ustanawiających porządek prawny i społeczny w kraju) i odnosi się nie tylko do braku równowagi w traktowaniu poszczególnych grup „przybyszów”, ale i do poczucia niesprawiedliwości wskutek gorszego względem innych grup traktowania własnych rodaków, podczas gdy, w mniemaniu repatriantów, to właśnie oni powinni cieszyć się większym niż "obcy imigranci” zrozumieniem i szacunkiem. W wypowiedzi repatriantki, urażonej przyjaźniejszym stosunkiem Polaków do Czeczeńców, pobrzmiewa ta sama retoryka, która każe w pierwszej kolejności pomagać Polakom na Wschodzie, a nie uchodźcom. Widać zatem jak trwały i powszechny jest schemat dotyczący reguł poświęcania uwagi, tolerancji i dystrybucji pomocy w zależności od statusu jednostek opartego na przynależności narodowej, państwowej, kulturowej czy nawet cywilizacyjnej i jak trudno w tym dyskursie o uznanie argumentów odwołujących się do wspólnego losu, czy wartości ogólnoludzkich. Korzystając z figury Zygmunta Baumana można powiedzieć, że od momentu utworzenia państw narodowych wciąż tkwimy w więzieniu wzniesionym przez połączone siły terytorium, narodu, państwa, w którym prawa człowieka definiuje się jako efekt połączenia w jednej osobie obywatela państwa, członka narodu i lojalnego mieszkańca terytorium (Bauman 2003: 298). Zdaniem filozofa jedynie słuszne, bo moralne podejście rozwiązujące problem uchodźców odsyłałoby do wspólnoty ludzkiej, globalnej, opartej na człowieczeństwie oraz wolności wszystkich jednostek, wolności od pozycji, rangi i narodowości. Brak globalnych instytucji oraz globalnie przyjętych zasad etycznych uniemożliwiają jednak jej powstanie (tamże 297-298).

18 Słowa byłej senatorki, posłanki do Parlamentu Europejskiego, Beaty Gosiewskiej w audycji z 17.11.2017 r. na temat nowelizacji ustawy o repatriacji. 
Opisywana tu wspólnota losu nawiązuje do baumanowskiej wspólnoty globalnej w stopniu, w jakim abstrahuje od narodowych, terytorialnych, państwowych, kulturowych i innych ograniczeń. Wracając na koniec do postawionego na wstępie pytania, wydaje się, że powoływanie się na wspólnotę losu może być skuteczne jedynie w określonych okolicznościach. W opisywanym przypadku przegrywa ona ze wspólnotą narodową, która jak się okazuje, mimo procesów globalizacyjnych, a być może jednocześnie dzięki nim (por. Nikitorowicz 2001:8), bywa najbardziej znaczącym rodzajem identyfikacji w konstrukcie zbiorowej tożsamości. Nie wydaje się, by świadomość wspólnych doświadczeń powoływała do życia rodzaj wyobrażonej zbiorowości, generującej procesy identyfikacyjne, tożsamościowe. Nawet jeśli tak jest, identyfikacja ta w sytuacji konkurowania z narodową okazuje się mało znacząca.

Wydaje się także, że doświadczenia, na które powołują się aktywiści w działaniach prouchodźczych są zbyt słabe i odległe w czasie, stąd ewentualna, oparta na nich wspólnota wydaje się bytem zbyt abstrakcyjnym. Mimo iż żywe i aktualne są dla wielu Polaków doświadczenia emigracji zarobkowej, migracji wahadłowych, sezonowych, to zbudowana na nim potencjalna wspólnota z innymi migrantami przegrywa z kontrargumentami takimi jak nieprzezwyciężalna obcość kulturowa, nieeuropejskość i niechrześcijańskość przybywających do Europy uchodźców.

Ogromne znaczenie dla omawianego zjawiska ma, praktykowana od jakiegoś czasu w wielu państwach w Europie i na świecie, nacjonalistyczna polityka, manipulująca za pomocą migrantofobii i islamofobii, wzbudzająca niepokoje społeczne i nastroje ksenofobiczne (por. Bobako 2017). Jak pisze Paweł Borkowski, głównym uwarunkowaniem polityki europejskiej (w rozumieniu całości zarówno sfer narodowych, jak i unijnej) jest dzisiaj strach (Borkowski 2017: 43). Sytuacja poczucia zagrożenia, w obliczu realnego bądź wyimaginowanego, wspólnego wroga, które zdominowało wiele społeczeństw europejskich, wymaga raczej konsolidacji wspólnoty skupionej wokół wartości podtrzymujących zbiorową tożsamość - a więc różnicujących, a nie jednoczących - niż jej zawieszenia na rzecz wartości ogólnoludzkich i humanitarnych. Tożsamość ta funkcjonuje w dyskursie uchodźczym na poziomach, które mogą przyjąć postać narodową, ale także ogólnoeuropejską, czy cywilizacji Zachodu, z których jedynie dwie pierwsze mają realnie wytyczone granice i organy instytucjonalne. Oscylując pomiędzy dążeniem do wspólnoty, a chęcią uwolnienia się od jej ograniczeń (Burszta 2004: 171-172), w powodowanych strachem dążeniach do zawężania swej solidarności do wspólnoty dającej bezpieczeństwo, wybór pada (poniekąd także w wyniku nacisku Unii Europejskiej na przyjmowanie niechcianych uchodźców) na najbardziej realną, sprawczą i pewną pod tym względem wspólnotę narodową reprezentowaną przez państwo czy to obywatelskie, czy jak w przypadku Polski - narodowe. Wydaje się, że w związku z sytuacyjnym charakterem „refleksyjnego poczucia narodowości" (Kłoskowska 2005: 87) mamy obecnie do czynienia z jego wzmożeniem. Jak przestrzega Smith „tożsamości narodowe bywają 'ekspansywne' mogą one wchłaniać, podporządkować sobie i zabarwiać inne role i tożsamości 


\section{SM̂PP}

zwłaszcza w czasach kryzysu" (Smith 2009: 42), którego właśnie doświadczamy. Jak słusznie zauważają Wojciech J. Burszta i Krzysztof Jaskułowski, w obliczu braku jak dotąd nowych, instytucjonalnych ram dla globalistycznie pojmowanej solidarności społecznej, w państwach narodowych, które trwają nadal, jednak nie gwarantują dotychczasowego status quo, "gtównym wrogiem stają się (...) uchodźcy, imigranci i przedstawiciele mniejszości narodowych, o których mniema się, że mogą podważyć kruche już dzisiaj podstawy ładu społecznego i ekonomicznego" (Burszta, Jaskułowski 2005: 34, por. także Bauman 2003: 297).

Oddziaływanie polityki strachu wywołanego przez wyolbrzymienie istniejącego zagrożenia dobrze ilustruje przywołane już badanie TNS z 2015 roku. Dowiadujemy się dzięki niemu, że ze stwierdzeniem, „że Polska powinna przyjmować uchodźców, ponieważ kiedyś Polacy sami musieli opuszczać swój kraj z obawy przed prześladowaniami i byli wówczas przyjmowani przez inne państwa", zgadza się 45\% Polaków, podczas gdy $43 \%$ się z nim nie zgadza. Znamienne jest, iż w latach poprzedzających kryzys uchodźczy i towarzyszące mu niepokoje społeczne (lata 2004, 2005 i 2006) odsetek osób zgadzających się z powyższą opinią wynosił co najmniej 70\%.

Tendencja ta widoczna jest przede wszystkim w poglądach społecznych, choć znajduje też swoje odzwierciedlenie w środowisku naukowym, które także podzielone jest w kwestii uchodźców i imigrantów. W Polsce odbywają się konferencje o tematyce migracyjnej i uchodźczej zdominowane przez studentów i wykładowców bezpieczeństwa wewnętrznego, gdzie na wykładach inauguracyjnych uzasadnia się konieczność zwarcia szyków w obronie "rodzimej kultury” przed napływem uchodźców nie w oparciu o fakty dowiedzione naukowo, lecz interpretacje wydarzeń pojedynczych dziennikarzy. Bywa, iż refleksji nad losem współczesnych uchodźców brakuje tam, gdzie w założeniu powinna się pojawić. Gdy w 2016 roku uczestniczyłam w konferencji o polskich doświadczeniach uchodźstwa, podczas słuchania kolejnych wystąpień ukazujących uchodźcze losy Polaków jako całych grup, bądź znaczących dla polskiej kultury jednostek oraz towarzyszących im dyskusji, moje zaciekawienie różnorodnością poruszanych wątków ustępowało zdumieniu, iż zarówno w referatach, jak i w komentarzach, temat dzisiejszych uchodźców nie zaistniał wcale. Poszczególne tematy nie nawiązywały, choćby tylko w konkluzjach, do aktualnego i palącego problemu kryzysu uchodźczego, stąd można było odnieść wrażenie, że uchodźcze losy Polaków postrzegane są jako wyjątkowe i wyłącznie polskie doświadczenie, nie mające ani precedensu ani symbolicznej kontynuacji wśród innych grup dzisiejszych migrantów. Wychodziłam z obrad z poczuciem, że struna empatii, której choćby ciche brzmienie spodziewałam się usłyszeć na tego rodzaju spotkaniu naukowym, pozostała nietknięta. Z kolei na niezwykle dla mnie pouczającej, debacie filozoficznej poświęconej uchodźcom i multikulturalizmowi, która odbyła się w Opolu w 2016 roku'19,

${ }^{19}$ Nagrania z debaty można odsłuchać na stronie: https://filozofuj.eu/relacja-opolskiego-spotkaniao-uchodzcach-multikulturalizmie-wokol-nr-7-czasopisma-filozofuj-audio/ (dostęp: 01.03.2017). 
jedyny głos $^{20}$, który w jednoznaczny i zdecydowany sposób nawoływał do ponadnarodowej, nieuwarunkowanej, solidarnej, otwartej i w końcu chrześcijańskiej postawy, podkreślając przy tym rolę dawnych uchodźców w rozprzestrzenianiu się chrześcijaństwa w Europie, był przerażająco osamotniony wśród współdyskutantów na czele z publicznością, z której większość stała na stanowisku, iż owszem powinniśmy pomagać, ale w pierwszej kolejności... swoim.

\section{Bibliografia}

Anderson B. (1997), Wspólnoty wyobrażone, Kraków: Znak - Warszawa: Fundacja im. Stefana Batorego.

Babiński G. (1997), Pogranicze polsko-ukraińskie. Etniczność, zróżnicowanie religijne, tożsamość, Kraków: Nomos.

Barth F. (2004), Grupy i granice etniczne: społeczna organizacja różnic kulturowych, w: Badanie kultury. Elementy teorii antropologicznej. Kontynuacje, Warszawa, s. 348-377.

Bauman Z. (2003), Razem osobno, Kraków: Wydawnictwo Literackie.

Bobako M. (2017), Islamofobia jako technologia władzy: studium z antropologii politycznej, Kraków: Universitas.

Bloch N. (2017), Projekt „Wszyscy jesteśmy migrantami. (Od)zyskiwanie pamięci migracyjnej”, "Studia Migracyjne - Przegląd Polonijny", z. 1(163), s. 333-339.

Borkowski P. (2017), Wymiar polityczny uchodźstwa - wybrane problemy w kontekście europejskiego kryzysu migracyjnego, w: Wojtaszczyk K.A., Szymańska J. (red.), Uchodźcy w Europie. Uwarunkowania, istota, następstwa, Warszawa: Oficyna Wydawnicza ASPRA-JR, s. 32-45.

Brubaker R. (1998), Nacjonalizm inaczej, Warszawa-Kraków: Wyd. Naukowe PWN.

Burszta W. (2004), Różnorodność i tożsamość. Antropologia jako kulturowa refleksyjność, Poznań: Wydawnictwo Poznańskie.

Burszta W., Jaskułowski K. (2005), Mniejszości narodowe i etniczne a idea państwa narodowego na początki XXI wieku, w: M. Nijakowski (red.), Polityka państwa polskiego wobec mniejszości narodowych i etnicznych, Warszawa: Wydawnictwo Sejmowe, s. 13-34.

Czapka E. (2017), Wymiar społeczno-kulturowy uchodźstwa, w: Wojtaszczyk K.A., Szymańska J. (red.), Uchodźcy w Europie. Uwarunkowania, istota, następstwa, Warszawa: Oficyna Wydawnicza ASPRA-JR, s. 64-77.

Eberhardt P. (1994), Przemiany narodowościowe na Ukrainie XX wieku, Warszawa: Obóz.

Gorbaniuk J. (1998), Problemy adaptacji młodzieży polskiego pochodzenia ze Wschodu studiującej w Polsce - na przykładzie grupy studentów z Lublina, "Przegląd Polonijny” nr 3, s. 87-102. Grzymała-Kazłowska A., Grzymała-Moszczyńska H. (2012), Repatrianci z Kazachstanu - charakterystyka i główne problemy adaptacyjne, Warszawa: Komitet Badań nad Migracjami.

Iwanow M. (1991), Pierwszy naród ukarany. Polacy w związku radzieckim 1921-1939, Warszawa-Wrocław: PWN.

Jasiewicz Z. (1992), Polacy z Ukrainy w Kazachstanie. Etniczność a historia, „LUD” t. 75, s. 11-54. Kijas A. (1993), Polacy w Kazachstanie. Przeszłość i teraźniejszość, Poznań: Abos.

20 Głos ten należał do księdza profesora Joachima Piecucha z Instytutu Filozofii na Uniwersytecie w Opolu. 


\section{SM̂PP}

Klaus W., Ostaszewska-Żuk E., Szczepanik M. (2017), Fundusze Europejskie i ich rola we wspieraniu integracji cudzoziemców w Polsce, https://interwencjaprawna.pl/wp-content/uploads/2017/09/raport_po-FAMI_net.pdf (dostęp: 19.11.2018).

Kość-Ryżko K. (2011), "Nic mnie serce za Kazachstanem nie boli...".Wyzwania akulturacyjne polskich repatriantow z Kazachstanu, „Etnografia Polska”, t. 55, z. 1-2, s. 149-178.

Kozubal M. (2018), Repatriacji trzeba naprawdę chcieć, www.rp.pl/Repatrianci/304179913-Repatriacji-trzeba-naprawde-chciec.html

Książek J. (2018), Stamtąd - tu. Obrazy tożsamości kazachstańskich Polaków w kontekście repatriacji, Toruń: Wydawnictwo UMK.

Kuligowski (2018), Archipelagi empatii, „Czas Kultury”, s. 112-117.

Kupczak J. M. (1994), Polacy na Ukrainie w latach 1921-1939, Wrocław: Wydawnictwo Uniwersytetu Wrocławskiego.

Lesińska M. (2016), Upolitycznienie emigracji i diaspory. Analiza dyskursu politycznego w Polsce w latach 1991-2015, "Studia Migracyjne - Przegląd Polonijny”, z. 3(161), s. 11-30.

Łodziński S. (2017), „Niepolityczna polityka”? Kształtowanie się polityki migracyjnej w Polsce w latach 1989-2016 „Studia Migracyjne - Przegląd Polonijny”, z. 2(164), s. 39-66.

Łodziński S. (1997), Informacja sejmowa nr 586, Repatriacja osób narodowości lub pochodzenia polskiego w latach 1989 - 1997. Problemy prawne i instytucjonalne, http://biurose.sejm. gov.pl/teksty/i-586.htm.

Nikitorowicz J. (2001), Wprowadzenie, w: Nikitorowicz i in. (red.), Kultury tradycyjne a kultura globalna. Konteksty edukacji międzykulturowej. Tom 1, Białystok: Transhumana.

Obrębski Józef 2005, Dzisiejsi ludzie Polesia i inne eseje, Kraków: Wyd. IFiS PAN.

Patek A. (2001), Polska diaspora w Rosji Radzieckiej i Związku Socjalistycznych Republik Radzieckich, w: Walaszek A. (red.), Polska diaspora, Kraków: Wydawnictwo Literackie, s. 293-325.

Repatriacja jako element polityki demograficznej Polski, Materiały z konferencji Poznań, 13-14 grudnia 2003, Poznań: Stowarzyszenie „Wspólnota Polska”.

Sadowski A., Czerniawska M. (1999), Tożsamość Polaków na pograniczach, Białystok: Wydawnictwo Uniwersytetu w Białymstoku.

Smith A.D. (2009), Kulturowe podstawy narodów, Kraków: Wyd. UJ

Smolicz J. (1984), Rdzeń kulturowy a tożsamość etniczna, „Studia Polonijne”, t. 8, Lublin, s. $33-46$.

Stroński H. (2007), Ucieczki, deportacje i repatriacje Polaków z Ukrainy w XX wieku: etapy, rozmach, specyfika, skutki, „Przegląd Polonijny” XXXIII, z. 4, s. 91-108.

Znaniecki F. (1930), Studia nad antagonizmem do obcych, "Przegląd Socjologiczny”, t. 1, s. 158-209. 